\title{
THE INFLUENCE OF EMPLOYMENT AND OCCUPATION ON A HOUSEHOLD'S NET EQUITY
}

\author{
Hermanus Combrink* \\ University of South Africa
}

Received: April 2016

\author{
Jan Venter" \\ University of South Africa
}

Accepted: July 2016

\begin{abstract}
Many South Africans are faced with the reality of poverty. Studies have shown that one of the best ways to alleviate poverty is through employment. Considering South Africa's high unemployment rate, it is clear that unemployment contributes to poverty and low household net wealth. Using data obtained from a representative omnibus sample, this paper analysed the effect of employment status on a household's net equity (assets minus liabilities). Whilst being employed did statistically significantly influence the household's net equity, there was an almost equal distribution of households over the net equity quintiles, indicating that employment status alone is not a guarantee of economic emancipation. In order to determine the cause of the equal distribution, the paper investigated whether the occupation in which a person is employed might assist in explaining the differences in the net equity values. It was found that being employed in certain occupations did to a statistically significant degree explain the differences in the net equity of households, with the households of persons employed in scarce skills occupations, on average, having a significantly higher net equity than the households of persons employed in a non-scarce skills occupation.
\end{abstract}

Keywords

Household, net equity, net wealth, employment status, occupation, South Africa, scarce skills, non-scarce skills

*Mr HA Combrink is a senior lecturer in the Department of Financial Governance, University of South Africa, South Africa [combrha@unisa.ac.za].

\#Prof JMP Venter was a professor in the Department of Financial Intelligence, University of South Africa, South Africa. 


\section{INTRODUCTION}

Internationally more than 2.1 billion people live on less than US\$3.10 a day (the international guideline for measuring poverty) (World Bank 2015). According to Statistics South Africa (2015) a significant proportion of the South African population live below the poverty line, mainly due to South Africa's high Gini coefficient of 0.63 (World Bank 2016). It is estimated by both organisations that approximately $37 \%$ of households in South Africa are earning less than R501 per month (at a purchasing power parity (PPP) of US $\$ 3.50$ per day). According to the Organisation for $\varepsilon$ conomic Co-operation and Development $(O E C D)$ the high number of citizens living below the poverty line can be ascribed to South Africa's high unemployment rate, which in turn contributes to poverty, crime and ill-health (OECD 2013a).

In order to assist vulnerable households, the South African government introduced several social support programmes, mainly through "social wages", which include social grants (most notably old-age pensions and child support grants), provision of basic services (water, electricity and sanitation) to households, free primary health care, free education (primary and secondary schools) and government-subsidised housing (Department of Government Communication and Information Systems (GCIS), 2015). Government does however recognise that in order to improve the quality of life of its citizens, job creation is of critical importance (The Presidency, 2014). Job creation and a reduction in the unemployment rate (currently at 24.5\% (Statistics South Africa, March 2016)), is one of the main focus points of the National Development Plan 2030:

In particular, South Africa must find ways to urgently reduce alarming levels of youth unemployment and to provide young people with broader opportunities. (National Planning Commission, 2011:26)

Various authors have pointed to the importance of employment in reaching personal finance objectives and financial wellbeing (Headey \& Wooden, 2004; Garman \& Forgue, 2011; Hira, Sabri, \& Loibl 2013; Kaseeram \& Mahadea, 2015). This paper contributes to this body of knowledge by firstly investigating whether employment has a significant effect on a South African household's net equity. Previous studies found that employment status is an important contributor to an increase in a household's net equity, although the mere fact that a person is employed does not guarantee that he will have a net equity (Momentum/Unisa, 2014). This finding leads to the question whether a person's type of job (occupation) influences his/her net equity. The Department of Labour annually publishes a list of scarce skills; basic economic principles suggest that employees working in these skills groups will earn a higher income (Department of Labour, 2010), which in turn will give them access to more financial services resulting in higher household net equity. The second contribution of the paper is to investigate whether a person's occupation has a significant influence on his/her household's net equity.

In order to achieve the two objectives of the study, the research firstly analysed the method applied to measure household net equity. This was followed by a description of the impact of employment and other factors on household net equity. In the final part of the paper, the net equity data obtained from 3222 respondents to the Momentum/Unisa South African household financial wellness omnibus survey (Wave 2) conducted by Unisa's Bureau for Market Research (BMR) was analysed using inferential statistics to determine whether employment status and occupation have a significant impact on household net equity. 


\section{RESEARCH OBJECTIVE AND HYPOTHESES}

The primary objectives of the study were to determine whether employment status and occupation have a significant influence on a household's net equity. To achieve the first objective of the study the following hypotheses were developed.

Hypothesis 10: Employment status does not have a significant influence on a household's net equity.

Hypothesis $1_{1}$ : $\quad$ Employment status has a significant influence on a household's net equity.

For the second objective of the study the following hypotheses were developed.

Hypothesis 20: $\quad$ The occupation within which a person is employed does not have a significant influence on his/her household's net equity.

Hypothesis 21: $\quad$ The occupation within which a person is employed has a significant influence on his/her household's net equity.

Firstly, the concepts used in this study, namely household net equity and the factors influencing $a$ household's net equity, are discussed in the following section. Thereafter, the data is analysed by applying these concepts.

\section{HOUSEHOLD NET E९UITY}

Various studies have found that household net equity $(\varepsilon)$ is the primary indicator of household wealth and is normally defined as a household's assets (A) less its liabilities ( $L$ ) (Daniels, Finn, \& Musundwa, 2012; Lafrance \& LaRochelle-Côté, 2012; 0ECD, 2013b). This principle is based on one of the grounding theories of accounting, developed by Luca Pacioli in 1494, known as the accounting equation (Smith, 2013), namely Equity = Assets minus Liabilities.

The literature review found that different definitions of household net equity are used in different studies. This results in different assets and liabilities being included in the different studies and different valuation methods used in the different studies (Cantril, 1965; Strumpel, 1976; Porter \& Garman, 1993; Hartog \& Oosterbeek, 1998; Charles \& Hurst, 2001; Wilmoth \& Koso, 2002; Keister, 2004; Davies, Sandstrom, Shorrocks, \& Wolff 2008; Davies, 2008; Movshuk, 2010). The literature review further revealed that authors used the terms 'net worth', 'net equity', 'wealth' and 'net wealth' interchangeably. For the purpose of this study the term 'net equity' was used for this concept.

Studies investigating net equity can be divided into two groups, namely those investigating net equity from a macroeconomic perspective, and those using a microeconomic perspective (Charles \& Hurst, 2001; Davies et al., 2008; United Nations, European Commission, Organisation for Economic Co-operation and Development, International Monetary Fund \& World Bank Group, 2009; Lafrance \& LaRochelle-Côté, 2012; Daniels et al., 2012; 0ECD, 2013b). This study made use of data collected at a microeconomic level and therefore falls into the second group of studies.

Scheepers (2013) developed the South African household Statement of Financial Position framework for assets and liabilities after a comprehensive review of household net equity studies 
done in Canada, the United States of America, Australia, New Zealand, European Union, India, Moldova, Indonesian and Turkey (see TABLE 1).

TABLE 1: South African household Statement of Financial Position framework for assets and liabilities

\begin{tabular}{|c|c|c|}
\hline & $\begin{array}{l}\text { Main } \\
\text { asset/liability } \\
\text { classification }\end{array}$ & Description of items included \\
\hline \multirow[t]{5}{*}{ ASSETS } & $\begin{array}{l}\text { Non-current } \\
\text { assets }\end{array}$ & Residential property and other property \\
\hline & $\begin{array}{l}\text { Other non- } \\
\text { financial } \\
\text { assets }\end{array}$ & $\begin{array}{l}\text { Vehicles, boats and planes, household content, collectibles, } \\
\text { trust assets and business assets }\end{array}$ \\
\hline & $\begin{array}{l}\text { Retirement } \\
\text { funding assets }\end{array}$ & Retirement funding assets \\
\hline & $\begin{array}{l}\text { Financial } \\
\text { assets }\end{array}$ & $\begin{array}{l}\text { Insurance, funeral insurance, special needs insurance, } \\
\text { educational policies, burial society policies, offshore } \\
\text { investments, unlisted shares, loan accounts, retail savings } \\
\text { bonds, employee share options and collective investments }\end{array}$ \\
\hline & Current assets & $\begin{array}{l}\text { Stokvel assets, listed shares, fixed deposits, other current } \\
\text { assets, savings accounts, money market investments, cheque } \\
\text { accounts, mzansi accounts and cash at home }\end{array}$ \\
\hline \multirow[t]{3}{*}{ LIABILITIES } & Mortgage loans & $\begin{array}{l}\text { Mortgage on residential property and mortgages on other } \\
\text { property }\end{array}$ \\
\hline & $\begin{array}{l}\text { Financial } \\
\text { liabilities }\end{array}$ & $\begin{array}{l}\text { Financing: } \\
\text { Vehicle financing, financing of boats and planes, household } \\
\text { content/collectible financing, other hire purchase agreements } \\
\text { and cell phone contracts, } \\
\text { Loans: } \\
\text { Student loans, personal loans, loan from employers, loan from } \\
\text { friend/relative/individuals, cash loans and other loans }\end{array}$ \\
\hline & $\begin{array}{l}\text { Current } \\
\text { liabilities }\end{array}$ & $\begin{array}{l}\text { Bank overdrafts, credit cards, store cards, petrol/garage cards, } \\
\text { household bills payable, municipal accounts, airtime accounts, } \\
\text { rent in arrear, alimony, school fees, SABC/DSTV/Toptv, medical } \\
\text { bills and other bills }\end{array}$ \\
\hline
\end{tabular}

Source: Scheepers (2013)

The $0 \varepsilon C D$ guidelines suggest that assets and liabilities should be measured at their current values in the market on the data collection date. The current value measurement method ensures that the results are reliable and coherent (OECD, 2013b) For the purpose of this study, assets and liabilities were measured at their current values as reported by the respondents at the reporting date (date of questionnaire). A limitation of any study using information to measure assets and liabilities at their current values is self-reporting risk in terms of which the value provided by a respondent might not approximate the current values at the reporting date (OECD, 2013b). To 
compensate for this risk the data collected from respondents was subjected to statistical tests to ensure reliability and validity of the data collected (see research methodology section).

\section{EFFECT OF EMPLOYMENT AND OCCUPATION ON HOUSEHOLD NET E९UITY}

Studies completed since the onset of democracy in South Africa have mainly focused on the alleviation of poverty (May, 2010), the results of government interventions (Leibbrandt, Woolard, Finn, \& Argent, 2010; Van der Berg, 2011), and the impact of social grants (Dua-Agyeman, 2005; Marais, 2011). This study contributes to the body of knowledge by evaluating the effect of employment status and more specifically the impact of occupational choice on the net equity quintile of South African households. Internationally both of these were found to have a significant influence on household net equity.

\subsection{Effect of employment}

Employment status has been found to be a major contributor to net equity, with Pawasutipaisit and Townsend (2011) pointing out that '... many households work their way out of poverty.' Friedline and Elliott (2011) confirmed this in their finding that employment status significantly affects a person's ability to accumulate savings (net equity). These savings are normally invested for later consumption or asset accumulation (Freedman 1957). Interestingly, Van Rooij, Lusardi, and Alessie (2011) concluded that whether a person is employed or self-employed does not significantly influence their net equity. The data used in this study did not allow for the further investigation as to whether this is also true in a South African context and this is a possible area for future research.

It is accepted that employment enables a person to save surplus income, which in turn allows the person to accumulate assets, enabling him/her to increase his/her net equity. This theory was confirmed by King and Leape (1998), who found that being employed increases the chances of a person investing in various types of assets. Baek and DeVaney (2004) found a positive correlation between income level whilst being employed and asset accumulation.

Daniels et al. (2012) found similar results in South Africa, namely that the unemployed have comparably lower net equity than the employed. A reason postulated is that the unemployed do not have access to assets (immovable and movable assets) due to limited access to debt for funding these assets.

\subsection{Effect of occupation}

Apart from being employed, research found that a person's type of work does have an impact on net equity. Internationally the occupation of the head of the household was found to explain some differences in family economic status, including net equity (Crystal, Shea, \& Krishnaswami, 1992; Yadollahi, Paim, Othman, \& Suandi, 2009). Monticone (2010) confirmed that the occupation type significantly influenced the net equity of a person, with managers and entrepreneurs having significantly higher levels of net equity compared to general employees (blue and white collar).

In their study on the difference in home-ownership, Hilber and Liu (2008) found that a person's type of occupation was significant in explaining the difference in home-ownership, traditionally the largest contributor to a household's asset value (Sheepers 2013). 
Although studies found that employment or occupation have a significant influence on a household's net equity, some studies revealed that this can also be influenced by other factors. Pfeffer and Hällsten (2012) researched the link between occupation levels reached and educational attainment and found a positive correlation that the higher the education, the higher the occupation level reached. The higher occupation levels in turn led to an increase in net equity. These findings were confirmed by Dmytro and Maria (2012).

Several studies investigating the relationship between net equity and age confirmed two personal finance grounding theories, namely Friedman's 'permanent income hypothesis' (1957) and Ando and Modigliani's (1963) 'lifecycle hypothesis' (Keister, 2004; Yadollahi et al., 2009; Pawasutipaisit \& Townsend, 2011; Van Rooij et al., 2011; Hira et al., 2013). In terms of these theories, individuals (or households) defer consumption leading to an accumulation of savings and wealth during a person's working lifetime, before dissaving takes place after retirement. It is therefore expected that net equity will increase with age before retirement. The OECD (2013b) points out that the correlation between age and net equity forms an integral part of any study into household net equity.

The next section will describe the process followed to collect the data used in this paper.

\section{RESEARCH METHODOLOGY}

The aim of this paper was to determine whether employment and more specifically occupation have a significant influence on a household's net equity. In order to achieve this objective the net equity per household was described as well as the employment status and occupational status of the household head. During the first stage of the analysis the effect of employment on the household's net equity was investigated. During the second stage of the analysis the group of respondents that were employed were analysed using their occupation to determine whether their occupation had a significant influence on their household's net equity. This study made use of household data; it is therefore important to note that a household is described as a wealth creation unit rather than an individual making a decision in isolation (Grosh \& Glewwe, 2000).

During the first phase, an archival research method was used, as historical documents, reports and articles were examined to identify information relevant to the topics under review (Cooper \& Schindler, 2014). The data used in the quantitative analysis stage of this paper (second phase of the research) was obtained from the Momentum/Unisa South African household financial wellness omnibus survey (Wave 2) conducted by Unisa's Bureau for Market Research (BMR). Permission was obtained from the data owners to use the data for academic purposes. The results presented in this study were based on the questions relating to the household's assets, liabilities and demographic factors included in the omnibus study.

The survey used a stratified multi-stage sample design to select the sample elements (individual household). The sample design plan ensured that the sample was a fair reflection of the South African household. Data obtained from the South African Demarcation Board (currently the Municipal Demarcation Board) was used to develop geo-demographic categories by means of a multi-stage sampling technique considering the cultural and ethnic diversity of South Africa. The diversity of the population was reflected in five geo-demographic categories, namely ruralurban, income, education, and racial and geographic characteristics. Using this sample framework, data was collected using both computer-aided telephone interviews (CATI) and personal face-to-face interviews. As stated previously, the study used the 'household' as unit of 
analysis. The definition of a household used in the survey corresponds to the definition used by Statistics South Africa when conducting surveys and is essentially that a household is viewed as a person or a group of persons who live and eat together as a unit for at least four days a week (Statistics South Africa, 2013).

The individual respondents were selected for the interview based on their ability to provide the most complete information on the household's finances (the financially knowledgeable person (FKP)). After completion of the interviews, the total realised sample was 3533 households, or $96.9 \%$ of the initial sample frame (response rate). The validity of the data was tested by using regression analysis to determine to what extent net equity (assets less liabilities) is determined by income sources. Based on the results of the regression analysis (low correlations and $R^{2}$ values), potential outliers were identified through the use of descriptive statistics and boxplots. Based on the results, 57 outliers were excluded from the dataset, which ensured acceptable correlation values. The dataset was further reduced by 224 respondents by eliminating those who did not indicate adequate asset and liability values, which are required to calculate their net equity value. All questionnaires that did not provide critical household demographics were also eliminated from the data set; this further reduced the dataset by 30 respondents.

The Cronbach Alpha coefficient was used to test the internal consistency of the components questionnaire. The construct consisted of seven Likert scale questions and had a coefficient value of 0.674 , which is above the exploratory threshold level of 0.6 (Hair, Black, Babin \& Anderson, 2010). The structural integrity of the data was analysed by using neural network methods to determine to what extent age, education and employment status could explain household income and expenditure. A value of $69 \%$ (linked to the \% contribution) was obtained, indicating a high level of structural integrity. After completing the validation and verification processes a usable sample of 3222 respondents was obtained.

TABLE 2: Rand value of household net equity

\begin{tabular}{llc}
\hline & \multicolumn{1}{c}{ Main asset/liability classification } & $\begin{array}{c}\text { Average rand value per } \\
\text { household }\end{array}$ \\
\hline ASSETS & Non-current assets & 372026 \\
& Other non-financial assets & 156964 \\
& Retirement funding assets & 48639 \\
& Financial assets & 10754 \\
\hline - LIABILITIES & Current assets & 29722 \\
& Mortgage loans & $(37508)$ \\
\hline & Financial liabilities & $(17931)$ \\
\hline
\end{tabular}

Source: Authors' analysis

The net equity per household was calculated by applying the South African household Statement of Financial Position framework to the data collected. The analysis revealed that the household with the highest net equity value had a value of R13 171300.00 and the lowest value had a negative net equity value of -R2 061932.26 . The average household net equity (mean) for 
respondents was $R 557802$. A breakdown of the asset and liabilities according to the framework is provided in TABLE 2.

To facilitate the statistical analysis of the data the respondents were divided into quintiles; TABLE 3 provides the details of the quintiles used in the remainder of the paper.

TABLE 3: Household net equity quintile

\begin{tabular}{lcccc}
\hline \multicolumn{1}{c}{ Puintile } & Range & Mean & $N$ & $\%$ \\
\hline Puintile 1 & -R2 061 932 to R17 775 & -R17 698 & 644 & 20.0 \\
Quintile 2 & R17 775 to R75 687 & R41 921 & 645 & 20.0 \\
Quintile 3 & R75 687 to R265 703 & R146 784 & 644 & 20.0 \\
Quintile 4 & R265 703 to R845 347 & R522 826 & 645 & 20.0 \\
Quintile 5 & R845 347 to R13 171 300 & R2 078 172 & 644 & 20.0 \\
\hline
\end{tabular}

Source: Authors' analysis

The previous descriptive analysis provided details on the dependent variable, namely net equity; the demographic profile of the realised sample is provided in TABLE 4 .

TABLE 4: Demographic profile of respondents

\begin{tabular}{|c|c|c|c|c|c|c|}
\hline \multirow{2}{*}{ Demographic group } & \multicolumn{3}{|c|}{ Total sample (Phase 1) } & \multicolumn{3}{|c|}{ Employed group (Phase 2) } \\
\hline & Mean & N & $\%$ & Mean & N & $\%$ \\
\hline \multicolumn{7}{|l|}{ Employment status } \\
\hline Unemployed & R175 672 & 431 & 13.6 & 0 & 0 & 0.0 \\
\hline Employed & R581 600 & 1994 & 62.8 & R581 600 & 1994 & 100.0 \\
\hline $\begin{array}{l}\text { Economically inactive } \\
\text { (Retired and students) }\end{array}$ & R706 547 & 748 & 23.6 & 0 & 0 & 0.0 \\
\hline \multicolumn{7}{|l|}{ Occupation } \\
\hline Managers & R1 043859 & 295 & 9.3 & R1 043859 & 295 & 14.8 \\
\hline Professionals & R1 044359 & 205 & 6.5 & Rl 044359 & 205 & 10.3 \\
\hline $\begin{array}{l}\text { Technicians and Associate } \\
\text { Professionals }\end{array}$ & R604 847 & 319 & 10.0 & R604 847 & 319 & 16.0 \\
\hline Clerical Support Workers & R277 699 & 124 & 3.9 & R277 699 & 124 & 6.2 \\
\hline Service and Sales Workers & R415 687 & 231 & 7.3 & R415 687 & 231 & 11.6 \\
\hline $\begin{array}{l}\text { Skilled Agricultural, Forestry, } \\
\text { Fishery, Craft and Related } \\
\text { Trades Workers }\end{array}$ & R521 514 & 290 & 9.1 & R521 514 & 290 & 14.5 \\
\hline $\begin{array}{l}\text { Plant and Machine Operators, } \\
\text { and Assemblers }\end{array}$ & R382 592 & 189 & 6.0 & R382 592 & 189 & 9.5 \\
\hline
\end{tabular}


Combrink \& Venter

\begin{tabular}{|c|c|c|c|c|c|c|}
\hline Elementary occupations & R190 133 & 209 & 6.6 & R190 133 & 209 & 10.5 \\
\hline Unspecified & R386 273 & 132 & 4.2 & R386 273 & 132 & 6.6 \\
\hline Unemployed & R174 978 & 532 & 16.8 & 0 & 0 & 0.0 \\
\hline $\begin{array}{l}\text { Economically inactive } \\
\text { (Retired and students) }\end{array}$ & R706 547 & 649 & 20.4 & 0 & 0 & 0.0 \\
\hline \multicolumn{7}{|l|}{ Household head age } \\
\hline 29 and under & R176996 & 289 & 9.1 & R205 053 & 215 & 10.9 \\
\hline $30-44$ & R349 223 & 880 & 27.6 & R365 155 & 746 & 37.9 \\
\hline $45-59$ & R648 449 & 1058 & 33.2 & R750 828 & 814 & 41.3 \\
\hline 60 and over & R759 149 & 959 & 30.1 & Rl 141809 & 194 & 9.9 \\
\hline \multicolumn{7}{|l|}{ Marital status } \\
\hline Never married and single & R231 232 & 597 & 18.7 & R233909 & 372 & 18.7 \\
\hline $\begin{array}{l}\text { Married or living together as } \\
\text { partners }\end{array}$ & R697 191 & 1883 & 58.9 & R694 651 & 1344 & 67.7 \\
\hline $\begin{array}{l}\text { Widowed, separated or } \\
\text { divorced }\end{array}$ & R459 688 & 717 & 22.4 & R509 130 & 270 & 13.6 \\
\hline \multicolumn{7}{|l|}{ Household head gender } \\
\hline Male & R640 214 & 2077 & 64.7 & R638 504 & 1485 & 74.7 \\
\hline Female & R396 726 & 1135 & 35.3 & R411651 & 503 & 25.3 \\
\hline \multicolumn{7}{|l|}{ Household head education } \\
\hline No schooling / Primary school & R155 487 & 556 & 17.5 & $\mathrm{R} 150651$ & 227 & 11.5 \\
\hline Grade 10 or less & R352 586 & 864 & 27.2 & R344 695 & 476 & 24.1 \\
\hline Grade 12 & R617042 & 987 & 31.1 & R569893 & 694 & 35.1 \\
\hline $\begin{array}{l}\text { Diploma / Degree / Post- } \\
\text { graduate degree }\end{array}$ & Rl 005720 & 768 & 24.2 & R965 924 & 580 & 29.3 \\
\hline \multicolumn{7}{|l|}{ Household income } \\
\hline Less than R1 399 & R187399 & 338 & 12.7 & R159306 & 106 & 6.4 \\
\hline R1 400 - R2 499 & $\mathrm{R} 238124$ & 399 & 15.0 & R203 260 & 151 & 9.2 \\
\hline R2 500 - R4 999 & R232 766 & 439 & 16.5 & R147 255 & 223 & 13.5 \\
\hline R5 000 - R7 999 & R320 524 & 313 & 11.8 & R269378 & 206 & 12.5 \\
\hline R8 $000-10999$ & R458 141 & 239 & 9.0 & R374 892 & 175 & 10.6 \\
\hline R11 000 - R19999 & $\mathrm{R} 687218$ & 312 & 11.7 & R524 866 & 229 & 13.9 \\
\hline R20 000 or more & Rl 057094 & 623 & 23.4 & R999 084 & 558 & 33.9 \\
\hline
\end{tabular}


Province

\begin{tabular}{lllllll} 
Eastern Cape & R492 138 & 337 & 10.5 & R506743 & 186 & 9.4 \\
\hline Free State & R611969 & 360 & 11.2 & R628730 & 247 & 12.4 \\
\hline Gauteng & R574 204 & 396 & 12.3 & R580506 & 267 & 13.4 \\
\hline KwaZulu-Natal & R432 600 & 422 & 13.1 & R513636 & 213 & 10.7 \\
Limpopo & R457 343 & 279 & 8.7 & R516269 & 170 & 8.6 \\
\hline Mpumulanga & R541311 & 350 & 10.9 & R524311 & 230 & 11.6 \\
\hline Northern Cape & R518398 & 360 & 11.2 & R515733 & 250 & 12.6 \\
\hline North-West & R599009 & 288 & 9.0 & R647258 & 193 & 9.7 \\
\hline Western Cape & R730 347 & 422 & 13.1 & R775 288 & 230 & 11.6 \\
\hline
\end{tabular}

Source: Authors' analysis

In order to determine whether the independent variables (employment status and occupation) had a statistically significant influence on the household net equity category, the Pearson's Chisquare test was used. The Pearson's Chi-square test determines the significance of relationships between two categorical variables (Pallant, 2005). In cases where respondents did not provide all the independent variables pair-wise exclusions were applied.

\section{RESULTS AND DISCUSSION}

The data analysis firstly provides descriptive statistics of the variables under review followed by the results of the inferential analysis (Pearson's Chi-square test) for the variables under review.

\subsection{Effect of employment on household net equity}

In order to evaluate the effect of employment on net equity, respondents were divided into three groups:

- Employed: respondents who indicated that they are employed;

- Unemployed: respondents who are not employed and not economically inactive;

- Economically inactive: Respondents who are retired, housewives or students.

The results of the analysis are provided in FIGURE 1.

A visual inspection of the results presented in FIGURE 1 indicates that for the unemployed group, Quintile 1 and Quintile 2 had the highest proportion of respondents. It is however interesting to note that some of the unemployed respondents were part of the higher quintiles. This can partly be ascribed to the social wages provided by government, as these respondents included households that receive free housing and used their grants to accumulate other assets.

The result also indicated that the biggest proportion of the economically inactive group is in Quintile 5 with an increasing trend. Due to the combined nature of this group further analysis of the results was required. The analysis for this group is provided in FIGURE 2. 


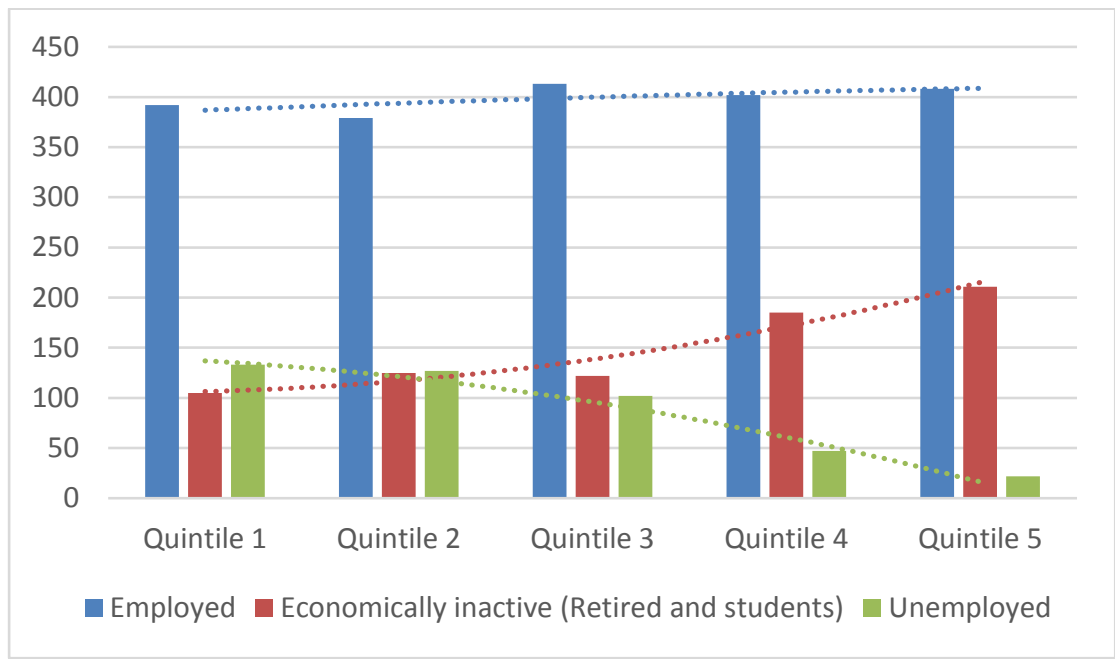

\section{FIGURE 1: Effect of employment group on net equity quintile}

Source: Authors'analysis

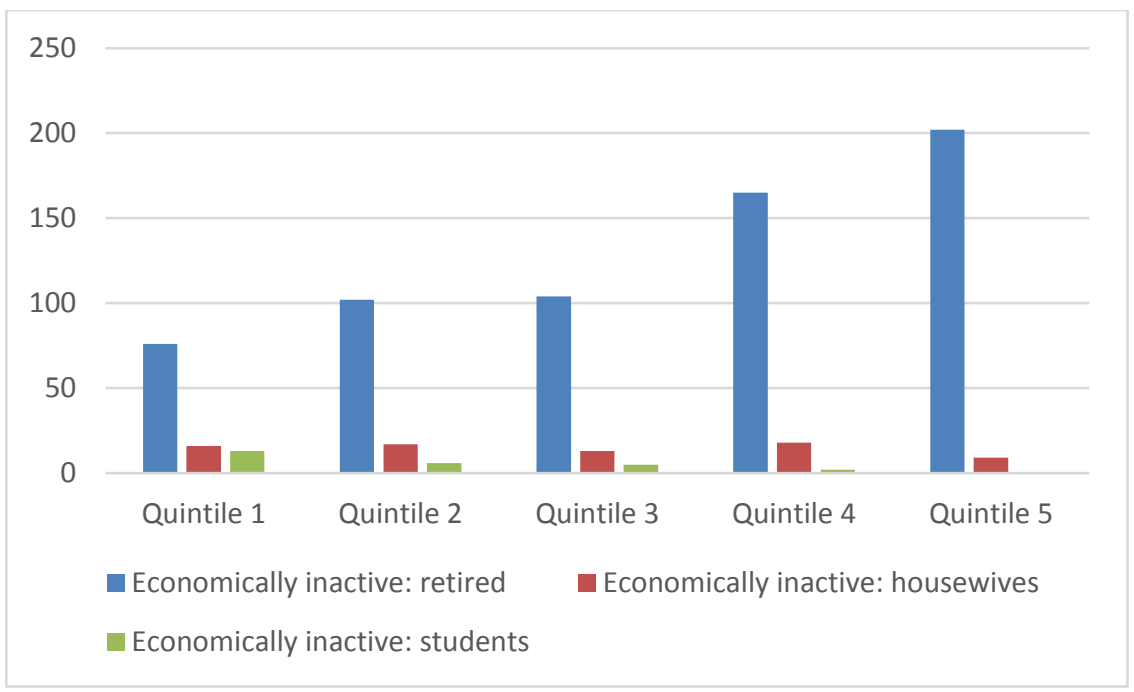

\section{FIGURE 2: Analysis of economically inactive group per net equity quintile}

\section{Source: Authors'analysis}

The results provided in FIGURE 2 confirm the permanent income and lifecycle hypotheses. The majority of students are in the lower quintiles, as the majority of them are still at the start of their economic life. Similarly, a large proportion of retired respondents are in the higher quintiles, confirming the theories that people accumulate assets during their economic life whereafter consumption starts after retirement, resulting in a move down the quintiles.

An interesting finding from the results in FIGURE $l$ is that being employed does not result in a household ending up in higher quintile. In order to determine whether employment status does 
significantly influence the net equity of a household Pearson's Chi-square test was performed (TABLE 5).

TABLE 5: Analysis of effect of employment status on household net equity quintile

\begin{tabular}{lcccc}
\hline Factor & \multicolumn{3}{c}{ Pearson's Chi-square Test } \\
\cline { 2 - 4 } & $\chi^{2}$ & $d f$ & p-value \\
Employment status & $202.982^{a}$ & 8 & $0.000 * \star \star$ \\
\hline
\end{tabular}

Source: Authors' analysis

${ }^{a} 0$ cells $(0.0 \%)$ have expected count less than 5 . The minimum expected count is 105.73 .

$\star \star \star p<.001$ very highly significant

The statistical analysis found very highly statistically significant differences in the three employment groups. The results indicated that respondents in the unemployed group had lower net equity values when compared to the other groups, with retired respondents having the highest net equity. The results therefore indicated that null-hypothesis of the first hypothesis of the study can be rejected:

Hypothesis $1_{0}$ :

Employment status does not significant influence on a household's net equity.

The fact that there is no clear trend for the net equity per employed group raises the question whether the occupation within which a person is employed does in fact influence his/her household net equity. In order to determine whether occupation does have a significant impact on household net equity, only the 1994 respondents who indicated that they are employed will be analysed in the remainder of the paper.

\subsection{Effect of occupation on household net equity}

The questionnaire contained an open-ended question asking the respondents to indicate their occupation. The responses received were recoded into eight major category groups using the categories as determined in the Organising Framework for Occupations (Department of Labour, 2012) as well as an unspecified group for respondents indicating that they are employed but the occupation not specified:

- Managers;

- Professionals;

- Technicians and Associate Professionals;

- Clerical Support Workers;

- Service and Sales Workers;

- Skilled Agricultural, Forestry, Fishery, Craft and Related Trades Workers;

- Plant and Machine Operators, and Assemblers;

- Elementary occupations; and

- Unspecified.

The number of respondents per occupation is provided in TABLE 6 . 
TABLE 6: Demographic profile per occupation

\begin{tabular}{lcc}
\hline \multicolumn{1}{c}{ Occupation } & $\begin{array}{c}\text { Total } \\
\text { sample } \\
\text { (N) }\end{array}$ & $\%$ \\
\hline Managers & 295 & $14.79 \%$ \\
\hline Professionals & 205 & $10.28 \%$ \\
Technicians and Associate Professionals & 319 & $16.00 \%$ \\
Clerical Support Workers & 124 & $6.22 \%$ \\
Service and Sales Workers & 231 & $11.58 \%$ \\
Skilled Agricultural, Forestry, Fishery, Craft and Related Trades & 290 & $14.54 \%$ \\
Workers & 189 & $9.48 \%$ \\
Plant and Machine Operators, and Assemblers & 209 & $10.48 \%$ \\
Elementary occupations & 132 & $6.62 \%$ \\
Unspecified & 1994 & $100.00 \%$ \\
\hline Total & &
\end{tabular}

Source: Authors' analysis

For the remainder of the analysis the 132 respondent who only indicated that they are employed but did not specify their occupation were excluded from the analysis. The net equity distribution per occupation is provided in FIGURE 3.

A visual inspection of the results presented in FIGURE 3 indicates that the occupation a person selects does have a significant influence on a household's net equity. Elementary occupations and service and sales workers proportionately had the most respondents in Quintile 1. Comparatively, professionals and managers had the highest proportion of respondents in Quintile 5. Although the visual inspection revealed differences due to the occupation selected, the data was subjected to statistical tests to evaluate the significance of the differences; the results of the Pearson's Chi-square test performed are provided in TABLE 7.

TABLE 7: Analysis of effect of occupational status on household net equity quintile

\begin{tabular}{lcccc}
\hline \multirow{2}{*}{ Factor } & \multicolumn{3}{c}{ Pearson's Chi-square Test } \\
\cline { 2 - 4 } & $\chi^{2}$ & $d f$ & $p$-value \\
Occupation & $295.564^{\mathrm{a}}$ & 32 & $0.000 * \star \star$ \\
\hline
\end{tabular}

Source: Authors' analysis

${ }^{a} 0$ cells $(0.0 \%)$ have expected count less than 5 . The minimum expected count is 23.57 .

$\star \star \star p<.001$ very highly significant 


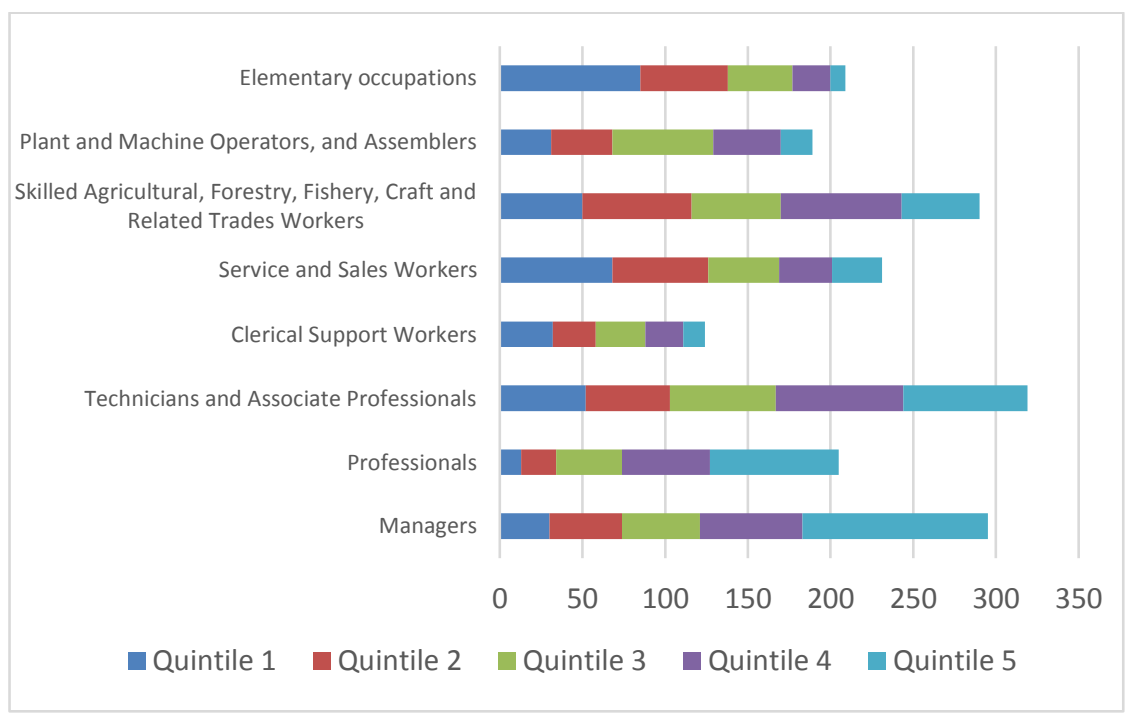

\section{FIGURE 3: Effect of occupation on net equity quintile}

Source: Authors'analysis

The statistical analysis found very highly statistically significant differences in the occupation groups, indicating that selecting the correct occupation does have a significant influence on a person and his/her household's net equity. The results therefore indicate that the null-hypothesis for the second objective can be rejected:

Hypothesis 20: $\quad$ The occupation within which a person is employed does not have a significant influence on his/her household's net equity.

As indicated, previous studies found that the education level does have a significant influence on a person's employment status and access to a specific occupation (Van Zyl, 2013). Despite the fact that government spends $19.2 \%$ of its budget on primary education and an additional $5.8 \%$ on post-school education and training (National Treasury 2016), several students are unhappy with access to education. This culminated in the recent "Fees must fall" movement (Eye Witness News, 2016). Based on the budget constraints government is experiencing, it is not in a position to provide free education to all (Gordhan, 2016). Based on the analysis done in this paper it is proposed that additional funding should be provided to train for occupations that have a higher probability of improving the household's net equity and therefore alleviating poverty not only for the direct family members but also for the extended family, which most South Africans support.

The question therefore arises which occupations should qualify for additional funding. The Department of Higher Education and Training has already identified several scarce skills that are needed to grow the South African economy (Department of Higher Education and Training, 2015). Applying the basic economic principles of supply and demand, it is submitted that employees in these occupations will earn higher incomes, and, as pointed out in the literature, this will enable them to accumulate more assets, resulting in a higher net equity. In order to test this submission, the list of scarce skills were analysed and compared to the individual occupations included in the eight groups used in this paper. This analysis found that of the identified scarce skills all fall within four occupation groups. To test whether obtaining scarce skills does in fact result in higher 
net equity values, the eight occupation groups were divided into two groups, namely scarce skills occupations and non-scarce skills occupations. Details of the two groups are provided in TABLE 8.

TABLE 8: Net equity distribution of scarce skills and non-scarce skills occupations

\begin{tabular}{llcc}
\hline Scarce skill group & Occupation & $N$ & $\%$ \\
\hline Scarce skills & - Managers & 1008 & $54.14 \%$ \\
& - Professionals & \\
& - Technicians and Associate Professionals & & \\
& - Plant and Machine Operators, and & & \\
& Assemblers & 854 & $45.86 \%$ \\
Non-Scarce skills & - Clerical Support Workers & & \\
& - Service and Sales Workers & & \\
& - Skilled Agricultural, Forestry, Fishery, & & \\
& - Craft and Related Trades Workers & & $100.00 \%$ \\
\hline
\end{tabular}

Source: Authors' analysis

The net equity quintile distribution for each of the two groups is provided in FIGURE 4.

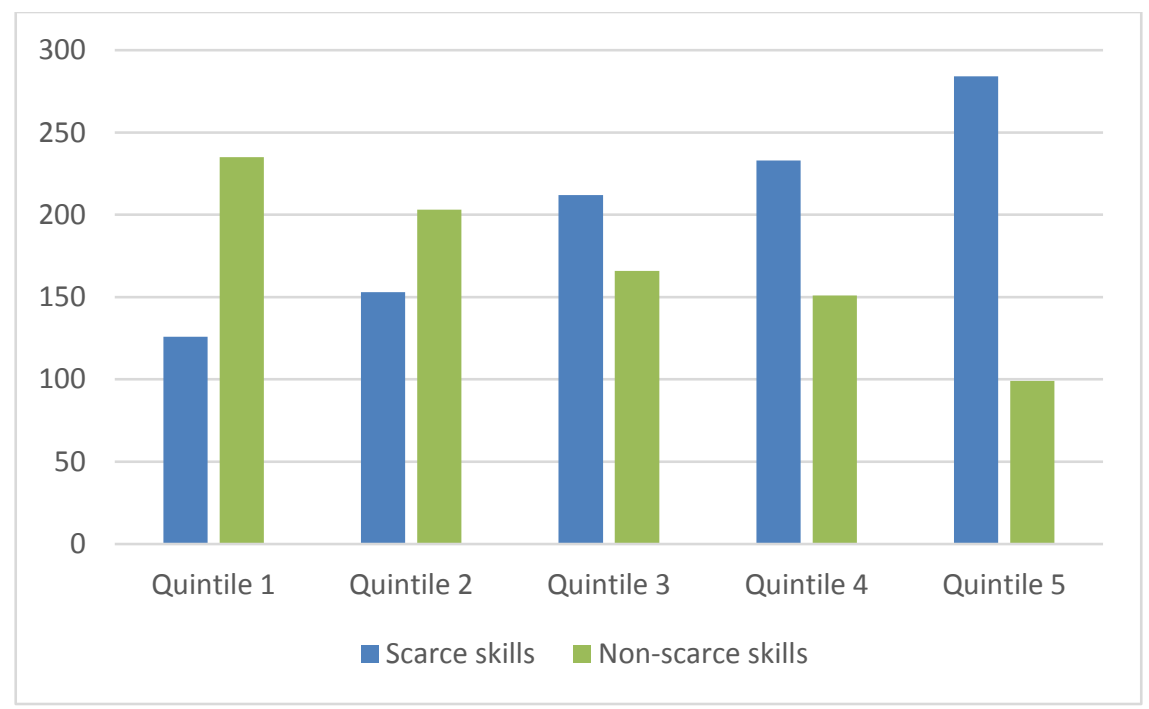

\section{FIGURE 4: Net equity quintile distribution of scarce skills and non-scarce skills occupations}

Source: Authors'analysis

It is clear from a visual inspection that there are more scarce skills employed persons in the higher net equity quintiles, with the non-scarce skills more concentrated towards the lower net equity quintiles. The data was subjected to statistical tests to evaluate the significance of the difference, and the results of the Pearson's Chi-square test performed are provided in TABLE 9. 
TABLE 9: Analysis of the effect of being employed in a scarce skill on household net equity quintiles

\begin{tabular}{llll}
\hline Factor & \multicolumn{2}{c}{ Pearson's Chi-square Test } \\
& $\chi^{2}$ & $d f$ & $p$-value \\
Scarce skill & 140.628 & 4 & $0.000 * \star \star$ \\
\hline
\end{tabular}

Source: Authors' analysis

${ }^{a} 0$ cells $(0.0 \%)$ have expected count less than 5 . The minimum expected count is 163.28 .

$\star \star \star p<.001$ very highly significant

The statistical analysis found very highly significant statistical differences in being employed in a scarce skill occupation which has a significant influence on a person and his/her household's net equity.

\section{CONCLUSION}

Previous international studies found that employment status is an important contributor towards an increase in a household's net equity. The results set out in this paper found that being employed compared to non-employed clearly leads to a greater average net equity, with the household net equity of an employed person averaging R581 600 compared to the household of an unemployed person averaging only R175 672. Despite the higher net equity that comes from being employed, the number of households across the net equity quintiles is more or less the same, indicating that being employed is in itself not an indicator of better living conditions.

When the employed group is analysed further, it is not surprising to find that the occupation group that leads to the highest average net equity is Professionals ( $R 1044359$ ) with the occupation with the lowest average net equity the Elementary occupations (R190 133). Apart from finding a job, it is clearly beneficial to choose a career path in one of the occupations that can lead to significantly higher net equity for the household. In this regard, the annual published scarce skills list can be of benefit, as the occupations that it lists as scarce (Managers, Professionals, Technicians and Associate Professionals and Plant and Machine Operators and Assemblers groups) generally lead to a higher net equity than the non-scarce skills list.

At a time when the government is facing increasing pressure for free higher education, the findings of the paper can assist in the prioritisation of funding towards certain qualifications which will enable the country to address the required skills shortage and in turn will lead to higher levels of household net equity for its citizens.

\section{Acknowledgement}

I would like to express my deepest gratitude to my co-author, mentor and friend Prof JMP Venter (Jan) who sadly passed away. You are my inspiration.

\section{LIST OF REFERENCES}

Ando, A. \& Modigliani, F. (1963). The "life cycle" hypothesis of saving: Aggregate implications and tests. The American Economic Review, 53(1 Part 1):55-84. 
Baek, દ. \& DeVaney, S.A. (2004). Assessing the baby boomers' financial wellness using financial ratios and a subjective measure. Family and Consumer Sciences Research Journal, 32(4):321-348.

Cantril, H. (1965). The pattern of human concerns. New Brunswick, NJ: Rutgers University Press.

Charles, K.K. \& Hurst, E. (2001). The correlation of wealth across generations. Journal of Political Economy, 111(6):1155-1182.

Cooper, D.R. and Schindler, P.S. (2014). Business Research Methods. $12^{\text {th }}$ ed. New York, NY: McGrawHill/Irwin.

Crystal, S., Shea, D., \& Krishnaswami, S. (1992). Educational attainment, occupational history and stratification: Determinants of later-life economic outcomes. Journal of Gerontology: Social Sciences, 47(5):S213-S221.

Daniels, R.C., Finn, A., \& Musundwa, S. (2012). Wealth in the National Income Dynamics Study Wave 2. Cape Town: SALDRU, University of Cape Town. (SALDRU Working Paper Number 83/ NIDS Discussion Paper 2012/5).

Davies, J.B. (2008). Personal wealth from a global perspective. Oxford: Oxford University Press.

Davies, J.B., Sandstrom, S., Shorrocks, A. \& Wolff, E.N. (2008). The world distribution of household wealth (No. 2008/03). WIDER Discussion Papers, World Institute for Development Economics (UNUWIDER).

Department of Government Communication and Information Systems (2015). South Africa Yearbook 2014/2015. Available: http://www.gcis.gov.za/content/resourcecentre/sa-info/yearbook2014-15. (Accessed 2 March 2016).

Department of Higher Education and Training (2015). List of occupations in high demand: 2015. Pretoria: Department of Higher Education and Training.

Department of Labour (2010). Scarce Skills. Available:

http://www.labour.gov.za/DOL/downloads/documents/useful-documents/skills-developmentact/Scarce\%20skills\%20pamphlet_pamphlet.pdf. (Accessed 2 March 2016)

Department of Labour (2012). The organising framework for occupations. Pretoria: Department of Labour.

Dmytro, H. \& Maria, L.P. (2012). The effect of education on equity holdings. The BE Journal of Economic Analysis \& Policy, 12(1):1-41.

Dua-Agyeman, A. (2005). Poverty alleviation in South Africa: Can government fiscal expenditure on social services make a difference? MCom thesis. Pietermaritzburg: University of KwaZulu-Natal.

Eye Witness News (2016). Fees must fall. Available: http://ewn.co.za/Topic/Fees-must-fall (Accessed 26 June 2016)

Friedline, T.L. \& Elliott, W. (2011). Predicting savings for White and Black young adults: An early look at racial disparities in savings and the potential role of Children's Development Accounts (CDAs). Race and Social Problems, 3(2):99-118.

Friedman, M. (1957). The permanent income hypothesis. In Friedman, M. eds. A theory of the consumption function, Princeton, New Jersey: Princeton University Press. 20-37.

Garman, દ.T. \& Forgue, R. (2011). Personal finance, $11^{\text {th }}$ edition. Cengage Learning.

Gordhan, P. (2016). Budget Speech. Available:

http://www.treasury.gov.za/documents/national\%20budget/2016/. (Accessed 5 March 2016). 
Grosh, M. \& Glewwe, P. (2000). Designing Household Survey Questionnaires for Developing Countries: Lessons from 15 Years of the Living Standards Measurement Study, Volume 2. Washington, DC: World Bank.

Hair, J.F.J., Black, W.C., Babin, B.J. \& Anderson, R.E. (2010). Multivariate data analysis 7 th edition. Upper Saddle River, CA: Pearson Prentice Hall.

Hartog, J. \& Oosterbeek, H. (1998). Health, wealth and happiness: Why pursue a higher education?. Economics of Education Review, 17(3):245-256.

Headey, B; \& Wooden, M. (2004). The Effects of Wealth and Income on Subjective Well-Being and IIIBeing. IZA Discussion paper series, No. 1032

Hilber, C.A.L. \& Liu, Y. (2008). Explaining the Black-White homeownership gap: The role of own wealth, parental externalities and locational preferences. Journal of Housing Economics, 17(2):152-174.

Hira, T.K., Sabri, M.F. \& Loibl, C. (2013). Financial socialization's impact on investment orientation and household net worth. International Journal of Consumer Studies, 37(1):29-35.

Kaseeram, I. \& Mahadea, D. (2015). Declining labour share of income in South Africa: the Kalman filter approach. Journal of Economic and Financial Sciences, 8(2):372-391.

Keister, L.A. (2004). Race, family structure, and wealth: The effect of childhood family on adult asset ownership. Sociological Perspectives, 47(2):161-187.

King, M.A. \& Leape, J.I. (1998). Wealth and portfolio composition: Theory and evidence. Journal of Public Economics, 69(2):155-193.

Lafrance, A. \& LaRochelle-Côté, S. (2012). The evolution of wealth over the life cycle. Perspectives on Labour and Income, 24(3):1-16.

Leibbrandt, M., Woolard, I., Finn, A. \& Argent, J. (2010). Trends in South African income distribution and poverty since the fall of apartheid. OECD Social, Employment and Migration Working Papers, no 101. Paris: OECD Publishing

May, J. (2010). Poverty eradication: The South African experience. Addis Ababa: United Nations Conference Centre.

Marais, H. (2011). South Africa pushed to the limit. The Political Economy of Change. Claremont: UCT Press.

Momentum/UNISA (2014). Household Financial Wellness Index. Available:

https://www.momentum.co.za/wps/wcm/connect/momVl/dcf4f6la-7d75-44be-8977-

3f76a7863b33/momentum-unisa-household-financial-wellness-index-2014-fullreport.pdf?MOD=AJPERES. (Accessed 3 March 2016).

Monticone, C. (2010). How much does wealth matter in the acquisition of financial literacy? Journal of Consumer Affairs, 44(2):403-422.

Movshuk, 0. (2010). Balance sheet effects on household consumption: Evidence from micro data. Toyama: Unpublished article.

National Planning Commission (2011). National Development Plan 2030: Our Future-Make It Work. Sherino Printers.

National Treasury (2016). Estimates of National Expenditure. FormeSet Printers Cape (Pty) Ltd Organisation for Economic Co-operation and Development (OECD) (2013a). OECD Economic Surveys South Africa. 0ECD Publishing. 
Organisation for Economic Co-operation and Development (OECD) (2013b). OECD Guidelines for micro statistics on household wealth. Paris: OECD Publishing.

Pallant, J. (2005). SPSS survival guide. Crow's Nest, NSW: Allen \& Unwin.

Pawasutipaisit, A. \& Townsend, R.M. (2011). Wealth accumulation and factors accounting for success. Journal of Econometrics, 161(1):56-81.

Pfeffer, F.T. \& Hällsten, M. (2012). Mobility regimes and parental wealth: The United States, Germany, and Sweden in comparison. Berlin: The German socio-economic (SOEP) papers on multidisciplinary panel data research No. 500.

Scheepers, D. (2013). Developing a statement of financial position model for the South African household sector. PhD thesis. Pretoria: University of South Africa.

Smith, M. (2013). Luca Pacioli: The father of accounting. Available: http://ssrn.com/abstract=2320658. (Accessed: 4 March 2016).

Statistics South Africa (Stats SA) (2013). General household survey. Pretoria: Statistics South Africa.

Statistics South Africa (Stats SA) (2015). Methodological report on rebasing of national poverty lines and development on pilot provincial poverty lines - Technical Report. Report No. 03-10-11. Pretoria: Statistics South Africa.

Statistics South Africa (Stats SA) (2016). Work and Labour Force. Available: http://www.statssa.gov.za/?page_id=737\&id=1. (Accessed 4 March 2016)

Strumpel, B. (1976). Economic means for human needs: Social indicators of well-being and discontent. Ann Arbor, MI: Institute for Social Research.

The Presidency (2014). Medium-term Strategic Framework (MTSF) 2014 - 2019. Department: Planning, Monitoring and Evaluation. Pretoria.

United Nations, European Commission, Organisation for Economic Co-operation and Development, International Monetary Fund \& World Bank Group (2009). System of National Accounts 2008. New York: United Nations Statistics Division.

Van der Berg, S. (2011). Current poverty and income distribution in the context of South African history. Economic History of Developing Regions, 26(1):120-140.

Van Rooij, M., Lusardi, A., \& Alessie, R. (2011). Financial literacy and stock market participation. Journal of Financial Economics, 101(2):449-472.

Van Zyl, H. (2013). The positive labour productivity externalities that arise from a post-secondary qualification or training. Journal of Economic and Financial Sciences, 6(3):761-772.

Wilmoth, J. \& Koso, G. (2002). Does marital history matter? Marital status and wealth outcomes among preretirement adults. Journal of Marriage and Family, 64(1):254-268.

World Bank (2015). Poverty Overview. Available:

http://www.worldbank.org/en/topic/poverty/overview. (Accessed 2 March 2016).

World Bank (2016). South Africa Economic Update-Promoting Faster Growth and Poverty Alleviation Through Competition. February 2016, Edition 8. Lynnwood: World Bank.

Yadollahi, M., Paim, L.H., Othman, M. \& Suandi, T. (2009). Factors affecting family economic status. European Journal of Scientific Research, 37(1):89-103. 